\title{
Locus of control in active physical therapy treatment for non-specific chronic low back pain
}

\author{
Lócus de controle no tratamento fisioterapêutico \\ ativo para dor lombar crônica inespecífica
}

\section{Alexandre Apolinário de Souza Batista ${ }^{[a]}$, Leandro Silva Rezende Diniz ${ }^{[\mathrm{a}]}$, Vinícius Cunha Oliveira ${ }^{[\mathrm{b}]}$, Claudia Venturini ${ }^{[a] *}$}

[a] Pontifícia Universidade Católica de Minas Gerais (PUC Minas), Betim, MG, Brazil

[b] Universidade Federal de Minas Gerais (UFMG), Belo Horizonte, MG, Brazil

\section{Abstract}

Introduction: The health locus of control is defined as the perception of individuals in relation to whom they believe to be responsible for their health condition, including low back pain. Objective: To identify whether individuals suffering from chronic low back pain in active physical therapy treatment believe they are responsible for their own condition. Material and methods: Cross-sectional study involving 28 patients under active physical therapy treatment for non-specific chronic low back pain. Sociodemographic data and low back characteristics - including disability and pain severity — were collected. The Multidimensional Health Locus of Control (MHLC) scale was used to assess the health locus of control. Results: Participants undergoing active low back pain treatment presented a mean (SD) of 26 points (11.40) in a 0-100 point scale for disability and 6.39 points (2.24) on a $0-10$ scale for pain. In relation to the health locus of control,

* AASB: undergraduate student, e-mail: batista.fisioterapia@gmail.com LSRD: undergraduate student, e-mail: leandrodiniz2010@hotmail.com VCO: PhD, e-mail: viniciuscunhaoliveira@yahoo.com.br CV: MSc, e-mail: venturinifisio@gmail.com 
the means (SD) for internal, external and chance subscales were, respectively: 29.32 (3.98), 24.75 (3.58), and 13.71 (6.67). 82.1\% of the participants presented higher rates for internal locus of control. Conclusion: Patients undergoing active treatment for chronic low back pain believe they are responsible for their own condition. Further longitudinal studies may determine whether active treatments affect the beliefs of low back pain patients.

Keywords: Chronic low back pain. Locus of control. Pain.

\section{Resumo}

Introdução: O lócus de controle de saúde é definido como a percepção do indivíduo quanto a quem ele acredita ser responsável por sua condição de saúde, incluindo a dor lombar. Objetivo: Identificar se indivíduos com dor lombar crônica em tratamento fisioterapêutico ativo acreditam que eles são responsáveis pela própria condição. Materiais e métodos: Estudo transversal que envolveu 28 pacientes em tratamento fisioterapêutico ativo para dor lombar crônica inespecífica. Características sociodemográficas e do quadro de dor lombar, incluindo incapacidade e severidade da dor, foram coletadas. O Questionário Multidimensional de Lócus de Controle da Saúde (QLCS) avaliou o lócus de controle da saúde. Resultados: Os participantes em tratamento ativo para dor lombar apresentaram em média (SD) 26 pontos $(11,40)$ em uma escala de 0-100 pontos para incapacidade e 6,39 pontos $(2,24)$ em uma escala de 0-10 pontos para dor. Com relação ao lócus de controle da saúde, a média (SD) para as subescalas interna, externa e acaso foram respectivamente: 29,32 (3,98), $24,75(3,58), 13,71$ $(6,67)$. Entre os participantes, $82,1 \%$ apresentaram maiores índices para lócus de controle interno. Conclusão: Pacientes realizando tratamento ativo para dor lombar crônica acreditam que eles são responsáveis pela própria condição. Futuros estudos longitudinais podem determinar se tratamentos ativos influenciam na crença dos pacientes com dor lombar.

Palavras-chave: Dor lombar crônica. Lócus de controle. Dor.

\section{Introduction}

Low back pain affects approximately $70 \%$ to $80 \%$ of workers in industrialized cities at some point in life, leading to cases of retirement due to functional disability (1). About 10 million Brazilians present disabilities due to low back pain (2) and 70\% of Brazilians will report episodes of pain at some point in life (3). Low back pain is considered a public health problem (4).

Studies show that biopsychosocial factors affect low back pain $(5,6,7)$. Among the psychosocial factors that interfere in low back pain, the health locus of control, defined as the beliefs of the individuals in relation to whom they believe to be responsible for their own health, has been under analysis (8-14). Individuals believing that others are responsible for their low back pain condition present higher rates of disability (9). These individuals prefer passive treatment, increasing dependence in relation to health services and the costs involved $(9,10)$. Therefore, active treatments could affect the beliefs of patients, consequently reducing their autonomy.

Nonetheless, active treatments in groups could increase the participation of patients and the therapeutic relationship, bringing significant clinical results. Even without evidence of greater effect in passive treatments, more active treatments should be sought to reduce dependence and costs.

It is unknown if active treatment in groups can influence the beliefs of individuals. Therefore, the present study aimed to investigate whether individuals suffering from low back pain undergoing active treatment believe they are responsible for their own health condition.

\section{Material and methods}

A cross-sectional study, approved by the Ethics Committee of the Pontifical Catholic University of Minas Gerais (PUC Minas), Belo Horizonte, Minas 
Gerais (15578513.8.0000.5137), was conducted. All the participants signed a free and informed consent form. Data were collected in two physical therapy clinical centers located in the city of Betim, metropolitan area of Belo Horizonte, Minas Gerais, Brazil.

The sample consisted of 28 male and female individuals. Inclusion criteria were: 1) age between 18 and 55 years; 2) presenting low back pain for more than three months; 3 ) currently undergoing active treatment with low back stabilization exercises and educational guidance with emphasis on self-treatment and control of their health condition; and 4) not presenting specific diagnosis for low back pain, such as tumors, trauma, infections, inflammatory disorders and motor and/or cognitive neurological deficit, nor being pregnant or in six months or less of postpartum.

Upon verification of the eligibility criteria and the signed free and informed consent form, the participants answered a sociodemographic questionnaire of disability and pain to characterize the sample. The sociodemographic questionnaire collected data on age, gender, marital status, educational level, duration of the symptoms in the low back and physical activity practiced by days of the week.

The characterization of the sample in relation to function was conducted through the Oswestry Disability Index, which evaluated the functional performance of the individuals in nine activities of daily living. It has ten sessions, each one has six options of answers, from 0 to 5 points. The final score ranges from $0 \%$ to $100 \%$, containing five classifications. Scores between $0 \%$ and $20 \%$ represent minimum disability, from $21 \%$ to $40 \%$ moderate disability, from $41 \%$ to $60 \%$ severe disability, from $61 \%$ to $80 \%$ disabled, and from $81 \%$ to $100 \%$ represent individuals who are probably confined to bed or present exaggerated pain exacerbation (15). Therefore, the lower the value obtained, the minimum the disability and the closer to 100, the greater the functional disability. This tool was validated and culturally adapted to Brazilian Portuguese, demonstrating Cronbach's alpha internal consistency of 0.87 and intraclass correlation coefficient (ICC) of 0.99 (16).

A short form of the McGill Pain Questionnaire was used to characterize pain. It qualitatively and quantitatively evaluated the dimensions of pain in a sensory and affective manner. The questionnaire contains 15 descriptors of pain sensation: 11 sensory (mechanical, thermal, vividness and spatial properties of the pain) and 4 affective (tension, fear and neurovegetative responses). Each descriptor is classified on a 4-point scale ranging between 0 (no pain), 1 (mild pain), 2 (moderate pain) and 3 (severe pain). The total result consists in the sum of the 15 descriptors with the score ranging from 0 to 45 , as affective pains have 0 to 12 and sensory pains have 0 to 33 points. The questionnaire was transcribed and culturally adapted to Brazilian Portuguese from a long version, obtaining ICC above 0.90 and Cronbach's alpha coefficient of 0.70 (17).

The Multidimensional Health Locus of Control (MHLC) scale was applied to evaluate the perception of individuals about whom they consider to be responsible for their current health condition. This instrument has 18 items ( 6 items per subscale) and the points of each subscale range from 6 to 36 . The three subscales of the instrument evaluate the internal (individuals consider themselves as responsible for their health condition), external (individuals believe other people are responsible for their health condition) or chance (health condition is given by fate or luck) health locus of control. This instrument was adapted to Brazilian Portuguese obtaining ICC of 0.75 to 0.95 (9).

Mean and standard deviation were used to report descriptive data considering normal distribution of data. For the interest outcome of health locus of control, mean deviation was reported for internal, external and chance subscales. The mean of the subscales was used to investigate predominant belief (health locus of control) of participants in active treatment. Frequency of participants with higher means in the internal, external and/or chance subscales were reported.

\section{Results}

Twenty-eight individuals under physical therapy treatment in two rehabilitation centers were considered eligible for the study. The characterization of the evaluated sample is presented in Table 1.

In relation to the functional disability evaluated by the ODI, mean and standard deviations were 26 and 11.61, respectively. Regarding the level of pain evaluated by SF-MPQ the mean was $21 \pm 8.90$. In relation to the qualitative sub-classification of pain, a predominance of sensory pain it was found in $78.6 \%$ of the evaluated sample. Other volunteers presented affective pain, corresponding to $21.4 \%$ of the cases (Table 1). 
Table 1 - Characterization of the sample

\begin{tabular}{|c|c|c|}
\hline Characteristics & Mean (SD) & N (\%) \\
\hline Age & $46.6(8.36)$ & 28 \\
\hline \multicolumn{3}{|l|}{ Gender } \\
\hline Male & & $4(14.3)$ \\
\hline Female & & $24(85.7)$ \\
\hline \multicolumn{3}{|l|}{ Marital status } \\
\hline Single & & $8(28.6)$ \\
\hline Married & & $14(50)$ \\
\hline Divorced & & $3(10.7)$ \\
\hline Widowed & & $3(10.7)$ \\
\hline \multicolumn{3}{|l|}{ Educational level } \\
\hline Illiterate & & $0(0)$ \\
\hline Incomplete elementary education & & $12(42.9)$ \\
\hline Complete elementary education & & $7(25)$ \\
\hline Incomplete middle school & & $2(7.1)$ \\
\hline Complete middle school & & $7(25)$ \\
\hline Incomplete higher education & & $0(0)$ \\
\hline Complete higher education & & $0(0)$ \\
\hline \multicolumn{3}{|l|}{ Duration of the symptons (months) } \\
\hline $3-12$ & & $3(10.7)$ \\
\hline $13-24$ & & $0(0)$ \\
\hline $25-36$ & & $2(7.1)$ \\
\hline$>36$ & & $23(82.1)$ \\
\hline \multicolumn{3}{|l|}{ Physical activity } \\
\hline Does not practice & & $26(92.9)$ \\
\hline $1-4$ days a week & & $1(3.6)$ \\
\hline 5-7 days a week & & $1(3.6)$ \\
\hline ODI & $26(11.40)$ & 28 \\
\hline SF-MPQ Total score & $21(8.73)$ & 28 \\
\hline SF-MPQ Sensory pain & & $22(78.6)$ \\
\hline SF-MPQ Affective pain & & $6(21.4)$ \\
\hline VASP & $6.39(2.24)$ & 28 \\
\hline
\end{tabular}

Note: $\mathrm{ODI}=$ Oswestry Disability Index; SF-MPQ = Short version of the McGill Pain Questionnaire; VASP: Visual Analog Scale for Pain; $\mathrm{SD}=$ Standard deviation. 
In relation to the health locus of control, $82.1 \%$ of the individuals see themselves as responsible for their current health condition (internal locus), 10.7\% believe other people are more responsible for their current condition than themselves (external locus) and $7.1 \%$ believe their condition occur due to fate or luck factors (chance locus). Means (SD) are reported in Table 2.

Table 2 - Mean and standard deviation of values of health locus of control

\begin{tabular}{lcc}
\hline Locus of control & Mean & SD \\
\hline Internal & 29.32 & 3.98 \\
External & 24.75 & 3.58 \\
\hline Chance & 13.71 & 6.67 \\
\hline
\end{tabular}

Note: $\mathrm{SD}=$ Standard deviation; Internal $=0-36$; External $=0-36$; Chance $=0-36$.

\section{Discussion}

A predominance of internal locus of control is found. It is possible that patients undergoing active treatment present more internal locus and lower dependence level, consequently reducing costs. Our study suggests that individuals undergoing active treatment have more internal locus, so active treatments could affect the beliefs of the individual and reduce costs related to low back pain. Our findings also confirm studies that found a preference for passive treatments - which increase dependence and costs $(9,10)-$ in individuals with external locus, as we find a predominance of internal beliefs for active treatment.

The study of Oliveira et al. (11), which investigated the beliefs of individuals undergoing treatment in comparison to those who were on the waiting list, showed a predominance of external beliefs in the group that was undergoing physical therapy treatment. It is possible that the differences found among Oliveira et al. (11), Harkapaa et al. (12) and the present study are related to the difference of the type of physical therapy treatment used among the studies. In this study, patients were undergoing active treatment in groups, which was characterized by lumbopelvic stabilization exercises associated with self-treatment instructions and guidance in relation to their health condition.

In the study by Oliveira et al. (11), patients underwent treatment for non-specific low back pain and stimulus to empowerment and self-treatment was not adopted. In the present study, the ability of control and empowerment on the health determinants of the participants may have determined the predominance of $82.1 \%$ of internal beliefs. This possible association confirms the findings of Harkapaa et al. (12), who found higher progress in the treatment for individuals with high internal locus of control as they had learned and practiced the exercises more often. It is possible that individuals with high internal locus of control tend to be more sensitive to empowerment and practice the prescribed exercises more often.

Literature has been showing that patients who undergo physical therapy treatment and who have external locus of control are more passive and present better response to mobilization therapies; on the other hand, those who have internal locus of control are more active, present better progress with motor control exercises and have a better prognosis (9). It is possible that in the present study the predominance of internal locus of control is explained by the tendency of adherence to group treatment, associated with health education, by patients with a more active profile and who consider themselves responsible for their health process. Studies that showed effects and preferences of patients with low back pain pointed out that the choice of the type of treatment according to the preference of the patient has association with the locus of control $(9,18)$.

The limitations of this study include failure to observe the number of conducted sessions and size of the sample, which reduced its power to verify association among the studied variables.

Future longitudinal studies should be conducted to confirm the influence of active treatments in the costs and beliefs of individuals suffering from low back pain.

\section{Conclusion}

The results of this study show that chronic low back pain patients undergoing low back active stabilization treatment associated with self-treatment and health education have predominance of internal beliefs, but they may also present external and chance beliefs. 
All the participants in this study were undergoing group treatment. This may have influenced the predominance of internal beliefs due to health education and self-care, a constantly adopted practice in chronic pain groups.

Further studies are suggested to analyze the impact of the type of care/treatment and beliefs of the physical therapists in the health locus of control.

\section{References}

1. Deyo RA, Cherkin D, Conrad D, Volinn E. Cost, controversy, crisis: low back pain and the health of the public. Annu Rev Public Health. 1991;12:141-56.

2. Teixeira MJ. Tratamento multidisciplinar do doente com dor. In: Carvalho MMMJ, organizador. Dor: um estudo multidisciplinar. São Paulo: Summus Editorial; 1999. p. 77-85.

3. Andersson G. Epidemiological features of chronic lowback pain. Lancet. 1999;354(9178):581-5.

4. Silva MCS, Fassa AG, Valle NCJ. Dor lombar crônica em uma população adulta do Sul do Brasil: prevalência e fatores associados. Cad Saúde Pública. 2004;20(2):377-85.

5. Linton SJ. A review of psychological risk factors in back and neck pain. Spine. 2000;25(9):1148-56.

6. Braman AC, Gomez RG. Patient personality predicts preference for relationships with doctors. Pers Individ Dif. 2004;37(4):815-26.

7. Koleck M, Mazaux JM, Rascle N, Bruchon-Schweitzer M. Psycho-social factors and coping strategies as predictors of chronic evolution and quality of life in patients with low back pain: a prospective study. Eur J Pain. 2006;10(1):1-11.

8. Oliveira VC, Furiati T, Sakamoto A, Ferreira P, Ferreira $\mathrm{M}$, Maher C. Health locus of control questionnaire for patients with chronic low back pain: psychometric properties of the Brazilian-Portuguese version. Physiother Res Int. 2008;13(1):42-52.

9. Oliveira VC, Ferreira PH, Ferreira ML, Tibúrcio L, Pinto RZ, Oliveira W, et al. People with low back pain who have externalised beliefs need to see greater improvements in symptoms to consider exercises worthwhile: an observational study. Aust J Physiother. 2009;55(4):271-5.
10. Haldorsen EM, Indahl A, Ursin H. Patients with low back pain not returning to work: a 12-month followup study. Spine. 1998;23(11):1202-7.

11. Oliveira TH, Oliveira VC, Melo RC, Melo RM, Freitas $\mathrm{AE}$, Ferreira PH. Patients in treatment for chronic low back pain have higher externalised beliefs: a crosssectional study. Rev Bras Fisioter. 2012;16(1):35-9.

12. Harkapaa K, Järvikoski A, Mellin G, Hurri G, Luoma $J$. Health locus of control beliefs and psychological distress as predictors for treatment outcome in lowback pain patients: results of a 3-month follow-up of a controlled intervention study. Pain. 1991;46(1):35-41.

13. Sengul Y, Kara B, Arda MN. The relationship between health locus of control and quality of life in patients with chronic low back pain. Turk Neurosurg. 2010;20(2):180-5.

14. Tait R, DeGood D, Carron H. A comparison of health locus of control beliefs in low-back patients from the U.S. and New Zealand. Pain. 1982;14(1):53-61.

15. Fairbank JC, Pynsent PB. The Oswestry Disability Index. Spine. 2000;25(22):2940-52.

16. Vigatto R, Alexandre NM, Correa Filho HR. Development of a Brazilian Portuguese version of the Oswestry Disability Index: cross-cultural adaptation, reliability, and validity. Spine. 2007;32(4):481-6.

17. Costa LCM, Maher CG, McAuley JH, Hancock MJ, Oliveira WM, Azevedo DC, et al. The Brazilian-Portuguese versions of the McGill Pain Questionnaire were reproducible, valid, and responsive in patients with musculoskeletal pain. J Clin Epidemiol. 2011;64(8):903-12.

18. King M, Nazareth I, Lampe F, Bower P, Chandler M, Morou M, et al. Conceptual framework and systematic review of the effects of participants' and professionals' preferences in randomised controlled trials. Health Technol Assess. 2005;9(35):1-186.

Received: $10 / 08 / 2014$ Recebido: 08/10/2014

Approved: 04/07/2015 Aprovado: 07/04/2015 